\title{
Az MKTOR piacorientációt mérő modell adaptációja és kapcsolata a vállalati teljesítménnyel
}

\author{
Kiss Marietta - Szakály Zoltán - Kovács Bence \\ Debreceni Egyetem
}

\section{A TANULMÁNY CÉLJA}

Tanulmányunk célja az volt, hogy megvizsgáljuk a hazai élelmiszeripari és mezögazdasági kis- és közepes vállalkozások piacorientációjának és vállalati teljesítményének kapcsolatát.

\section{ALKALMAZOTT MÓDSZERTAN}

A piacorientációt a nemzetközileg bemért MKTOR skála alapján határoztuk meg, melyet a magyar élelmiszeripari és mezőgazdasági szektorra adaptálva validáltunk feltáró és konfirmatorikus faktorelemzéssel. A vállalati teljesítményt egy szubjektív észlelésen alapuló, három dimenzióból álló indikátorral mértük. A primer kutatás alapját egy 250 elemủ, vállalati méretkategóriára és tevékenységi körre reprezentatív, kérdezőbiztos által mezőgazdasági és élelmiszeripari vállalatok marketingesei (ennek hiányában vezetői) körében felvett személyes megkérdezés szolgáltatta. A kapcsolatot a piacorientáció és a vállalati teljesítmény között strukturális egyenlet modellezéssel (SEM) teszteltük.

\section{LEGFONTOSABB EREDMÉNYEK}

Primer kutatásunk eredményei szerint a piacorientáció mérésére leggyakrabban alkalmazott MKTOR skála mára elavultnak tekinthető. A SEM segítségével továbbá pozitív kapcsolatot sikerült kimutatni a vállalatok piacorientációjának mértéke és a vállalati teljesítmény között, mely hasonlóképp mutatkozik meg a piacorientáció és a vállalati teljesítmény egyes dimenziói között is.

\section{GYAKORLATI JAVASLATOK}

A piacorientációval kapcsolatos kutatások módszertanának fejlesztése, a skálák adaptálása elengedhetetlen ahhoz, hogy a kutatók pontos képet kapjanak a vállalatok piacorientációjáról. Mivel a piacorientáció mértékének növekedése jobb vállalati teljesítményhez vezet, a vállalatoknak érdemes nagyobb hangsúlyt fektetniük a piacorientációjuk javítására.

Kulcsszavak: piacorientáció; MKTOR; vállalati teljesítmény; élelmiszeripar és mezőgazdaság

Köszönetnyilvánitás: A publikáció elkészítését az EFOP-3.6.2-16-2017-00003 számú projekt támogatta. A projekt az Európai Unió támogatásával, az Európai Szociális Alap társfinanszírozásával valósult meg.

DOI: 10.15170/MM.2020.54.KSZ.II.07 


\section{BEVEZETÉS INTRODUCTION}

A piacorientáció mind a közgazdaság-, mind a gazdálkodás-, mind pedig a szervezéstudományok népszerü fogalmai közé tartozik. Egyaránt megjelenik a menedzsment, a vállalatelméletek és a marketing diszciplína területén is, ám elsődlegesen ez utóbbi foglalkozik vele behatóan (Gyulavári és tsai 2011). Jelentőségét az is tükrözi, hogy a Marketing Science Institute az 1980-as években kiemelt törekvésként kezelte a fogalom meghatározását, területeinek feltárását és egy mérőeszköz kidolgozását (Deshpandé \& Farley 2004). A vállalati marketingtevékenység tudományos vizsgálatának egyik célja, hogy feltárják, miként kapcsolódik össze a piac komplex koordinációs mechanizmusa a vállalati törekvésekkel, létezik-e tökéletes „recept” a sikerre, avagy az idealizált vezérelvek alapján kialakított elméletek - akár gondolhatunk a marketingkoncepcióra is - hogyan ültethetők át a gyakorlatba sikeresen (Kontor \& Nyul 2016). Kohli és Jaworski (1990) értelmezésében ennek megfelelően a piacorientáció a marketingkoncepció gyakorlati megvalósításaként is értelmezhetö.

A piacorientációval kapcsolatos kutatások fellendülése az 1990-es évekre tehető, ekkor történt a magyar vállalatok piacorientációjának egyik első vizsgálata (Rekettye \& Gupta 1995), és ekkor látott napvilágot a ma is legelterjedtebb két, logikájában ellentétes filozófiát tükröző piacorientációs modell, a MARKOR skála, mely Kohli és Jaworski (1990) nevéhez füződik, valamint az MKTOR skála, amely Narver és Slater (1990) kutatásainak eredménye. Míg a MARKOR skála a piacorientációt vállalati magatartásként fogja fel, addig az MKTOR skála kulturális perspektíván alapszik (Kontor 2014a).

Jelen kutatás tárgyát az MKTOR skála alkotja, így ennek a felépítését mutatjuk be röviden. Narver és Slater (1990) elmélete szerint a piacorientáció mint kultúra három dimenzióból áll: a vevőorientációból, a versenytárs-orientációból és a szervezet funkcionális területeinek együttmúködéséből. Az elmélet alapja, hogy meg kell ismernünk a fogyasztóinkat annak érdekében, hogy kiemelkedő vevőértéket nyújtsunk számukra, továbbá versenyző iparágakban nem hagyhatók figyelmen kívül a versenytársak sem, erősségeik és gyengeségeik ismerete a stratégia kialakítása során és a taktikai döntések meghozatalában is jelentős szerepet játszik. $\mathrm{E}$ két dimenzió megvalósításához nélkülözhetetlen a funkcionálisan - vagy egyéb módon - tagolt szervezeteknél a szervezeti funkciók együttmüködése és koordinációja. E három komponens mellett a szerzők meghatároznak két további kritériumot is, melyeknek teljesülnie kell: a döntések meghozatala során a stratégiai, hosszú távú szemléletnek és a profitorientációnak is érvényesülnie kell (Narver \& Slater 1990).

A modell születése óta eltelt 30 évben nemcsak a piacorientáció szakirodalma bővült és fejlődött, de a piac is jelentős változáson ment keresztül. Számos kutatás vizsgálta a skálák érvényességét és hatásosságát, és jelentős részük egyetért abban, hogy a bekövetkezett változásokra reagálva szükséges az eszközök adaptációja (Bareith et al. 2013). Farrell (2002) összevetette a MARKOR és az MKTOR skála fejlesztési törekvéseit és arra a következtetésre jutott, hogy sok esetben megalapozatlan, ötletszerü módosításokkal, javításokkal találkozhatunk a szakirodalomban. Véleményünk szerint ugyanakkor szép számmal találunk módszertanilag megalapozott vizsgálatokat is. A módosításokat tanulmányozva úgy találtuk, hogy a kutatások két táborra szakadnak: egy részük pusztán kvantitatív eljárásokkal kísérli meg javítani a meglévő skálákat (Dawes 2000, Hajjat 2002, Harrison \& Walker 2001, Oczkowski \& Farrell 1998a, 1998b), vagy a Cronbach alfa mutatószámra alapozva, mely a skálák reliabilitását méri, vagy pedig - már fejlettebb, igazi többváltozós statisztikai eljárással - konfirmatív faktorelemzést alkalmazva vagy strukturális egyenlet modellezés segítségével. A másik tábor a szakirodalomra vagy kvalitatív vizsgálatokra (mélyinterjú, szakértői interjú, fókuszcsoport) helyezi a hangsúlyt és logikai alapon igyekszik a skálákat fejleszteni (Avlonitis \& Gounaris 1999). Az elöbbi csoport módszertana a meglévő skálákkal való vizsgálatokat készíti elö egy-egy adott mintán belüli megbízhatóság és illeszkedés mérésével, illetve a skálák adaptálásával. Az utóbbi, kvalitatív eljárások pedig a meglévő skálák felhasználásával - azokat egyfajta kiindulópontként kezelve vagy azoktól függetlenül - törekednek egy-egy új elméleti irány, valamint mérési eszközrendszer kidolgozására.

Számos kutatás bizonyítja a piacorientáció és a vállalati teljesítmény közötti pozitív kapcsolatot, épp emiatt lehet fontos szerepe a vállalati teljesítménynek a piacorientációs modellalkotás folyamán (Kontor 2014b). Tomáskova (2009) szerint a piacorientációba gyakran beépítik a vállalati teljesítményt egy kiegészítő dimenzióként, holott maga a teljesítmény nem a piacorientált kultúra/magatartás eleme, hanem annak egyik következménye. Ezzel egyetértve mi is úgy tartjuk, hogy a modellalkotás folyamán elsősorban moderátorként kell tekinteni a vállalati teljesítményre, nem pedig a piacorientáció egy külön dimenziójaként. 


\section{ANYAG ÉS MÓDSZER MATERIAL AND METHOD}

\section{Adatgyüjtés \\ Data collection}

A primer kutatás alapját egy kérdőives megkérdezés szolgáltatta, mely egy 100 elemủ mintán került tesztelésre, majd a tapasztalatok alapján átalakított végső kérdőív felvétele 2010-ben történt. A megkérdezést a Szocio-Gráf Piac- és Közvéleménykutató Intézet végezte, a mintába került 250 élelmiszeripari és mezőgazdasági vállalkozás marketingesével (annak hiányában felelős beosztású vezetőjével) végzett személyes adatfelvétel keretében. Az alapsokaság összetételének meghatározása a KSH 2009. december 31-én regisztrált létszám-kategóriák és szakágazat szerinti nyilvántartása alapján történt, a minta kialakításának alapját a KSH 2009. negyedik negyedévi CÉG-KÓD-TÁR kiadványában szereplő TEÁOR szám (10, kivéve $109 ; 11 ; 01 ; 03)$, valamint vállalati nagyság alapján végzett lekérdezés eredményeként kapott adatbázis képezte. A véletlenszerüséget egy véletlenszám-generátor biztosította, ami segített kiválasztani az adatbázisban szereplő vállalkozások közül a megkérdezésbe kerülőket. A minta így vállalati méretre és tevékenységi körre nézve reprezentatív.

A kérdőívben elöször Narver és Slater (1990) alapján a piacorientációt mérő MKTOR skála három dimenziójának 17 állítását (vevőorientáció 8 , versenytárs-orientáció 5 , funkciók közötti együttmüködés 4 állítás), majd a vállalat teljesítményét leíró 15 állítást kellett a válaszadóknak ötfokozatú Likert-skálán értékelni. A skálákat alkotó változókat a Melléklet tartalmazza.

\section{A statisztikai elemzés folyamata és eszközei \\ Process and tools of statistical analysis}

Az elemzés első blokkjában a piacorientációt mérő MKTOR és a vállalati teljesítményt mérő skála tesztelése és adaptálása történt. A megbízhatóságot külön-külön teszteltük az MKTOR skála három dimenziója esetén, illetve a vállalati teljesítmény skálánál, a Cronbach-féle alfa mutatót alkalmazva. $\mathrm{Az}$ alfa értékét tekintve általánosan elmondható, hogy a 0,8 fölötti érték jónak, míg a 0,9 fölötti érték kiváló megbízhatóságnak tekinthető (Cronbach 1951).

A piacorientációs skála teoretikus vizsgálata, azaz, hogy a skála három dimenzióját visszaadják-e elkülönülten a változók, feltáró (exploratív) faktorelemzéssel (EFA) történt, maximum likelihood eljárással, varimax rotációval és Kaiser normalizációval. Ez a többváltozós eljárás tökéletes arra, hogy kimutatható legyen a kapcsolat (vagy annak hiánya) az indikátorok és a látens változók között. Ha visszaadja az elemzés az elmélet alapján fennálló előre feltételezett struktúrát (a látens változókat), azaz a 17 változó három faktorral leírható, és a faktorstruktúrában az elmélet által megfogalmazott dimenziók jelennek meg, akkor a modell lényegi módosítása nem szükséges. Ennek első lépéseként vizsgáltuk az adatok megfelelőségét a szakirodalomban bevett KMO kritérium, Bartlett-próba és a Pearson-féle korrelációs együttható segítségével. A faktorok számát először a Kaiser-kritérium és a varianciahányad módszer alapján határoztuk meg, majd a priori becsléssel (a három dimenzió három faktort képezne az elmélet alapján).

A tényleges adaptáció ellenőrző (konfirmatorikus) faktorelemzéssel (CFA) történt (maximum likelihood eljárással, varimax rotációval és Kaiser normalizációval). A vizsgálat során megengedtük az ugyanazon látens változóhoz (dimenzióhoz) tartozó változók közti kovarianciát, amennyiben annak értéke kiugróan magasnak bizonyult. Majd mindaddig, amíg a modell illeszkedését mérő mutatóknak legalább a fele megfelelő eredményt nem adott a standardizált reziduális kovarianciamátrix alapján, eltávolítottuk egyesével azokat a változókat, melyek rontották a modell érvényességét és hatásosságát (Li 2016). A modell illeszkedésének megítélésére a szakirodalom alapján a következő mutatókat választottuk: $\mathrm{Khi}^{2}$-próba $p$-értéke, $\mathrm{CFI}$, GFI, RMSEA, RMSEA $p$-értéke, NFI. Ezt követően ismételt feltáró (exploratív) faktorelemzés végeztük az adaptált MKTOR skálával (Levine 2005).

A kutatás második fő blokkját a piacorientáció és a vállalati teljesítmény kapcsolatának vizsgálata alkotta. A szubjektív vállalati teljesítmény mérésére 15 változó állt rendelkezésre, ezek versenyképességet, eredményességet és hatékonyságot egyaránt mértek. Annak érdekében, hogy az adatok alapján megfelelően el tudjuk határolni a vállalati teljesítmény különböző dimenzióit, feltáró faktorelemzést végeztünk (maximum likelihood eljárással, varimax rotációval és Kaiser normalizációval), ami a következő lépésben végrehajtott adatredukció alapját képezte. A piacorientáció és a vállalati teljesítmény összefüggésének vizsgálatára a strukturális egyenlet modellezés (SEM) regressziós eljárását alkalmaztuk, mivel ez az eljárás tökéletesen alkalmas két látens változó determinisztikus kapcsolatának vizsgálatára. Mivel a SEM-ben a látens válto- 
zókat az indikátoraink (mérési modell) külön-külön határozzák meg (bár a kovariancia megengedhető), célszerünek láttuk az MKTOR három dimenziója, valamint a vállalati teljesítmény dimenzióinak adatredukcióját blokkonként/dimenziónként elkülönítve végrehajtani főkomponens-elemzéssel (forgatás nélkül), egyébként olyan változók is megjelentek volna az adott dimenzióban - még ha alacsony súllyal is -, amelyek nem kapcsolódnak közvetlenül hozzá.

A konfirmatorikus faktorelemzéshez és a strukturális egyenlet modellezéshez szükséges normális eloszlást és multinormalitást ferdeségi és csúcsossági mutatók alapján vizsgáltuk. A megbízhatóság vizsgálata, az exploratív faktorelemzés és az adatredukció során az IBM SPSS Statistics 22-es verzióját, a konfirmatorikus faktorelemzés és a strukturális egyenlet modellezés során pedig az IBM SPSS AMOS Graphics 23-as verzióját használtuk.

\section{EREDMÉNYEK RESULTS}

\section{A skálák megbizhatósága Reliability of scales}

A piacorientáció részét képező vevőorientáció skála Cronbach alfa értéke 0,876 , a versenytárs-orientációé 0,829 , a funkciók közötti együttműködésé pedig 0,859 , míg a vállalati teljesítményt mérő skála alfája 0,930. Egyik skála esetében sem érhető el, hogy a megbízhatóság javuljon egy-egy változó eltávolításával, azonban a piacorientáció dimenzióinak megbízhatósága így is jónak, a vállalati teljesítmény skáláé pedig kiválónak tekinthető az alfa mutatószám alapján (Cronbach 1951).

\section{Az MKTOR skála feltáró és ellenörzö faktorelemzésének eredményei Results of the MKTOR scale's explora- tory and confirmatory factor analyses}

Az MKTOR skála változói között közepes és erős lineáris korreláció tapasztalható, mely minden esetben pozitív és szignifikáns, ezt bizonyítja a KMO értéke is $(0,883)$. A Bartlett-próba alapján is megfelelnek a változók a faktoranalízis feltételeinek $(p<0,05)$. A feltáró faktorelemzés során a Kaiser-kritérium és a varianciahányad alapján négy faktor írja le legjobban a változókat. A második és a harmadik faktorban erős súlyokkal rajzolódik ki a versenytárs-orientáció és a funkcionális területek együttmüködése, az első és a negyedik faktorban pedig erős súlyokkal jelenik meg a vevőorientáció. Ha az a priori módszer alapján három faktort alakítunk ki, a kapott faktorokban a dimenziók jelentősen összemosódnak, azaz megállapítható, hogy a faktorstruktúrában nem igazolódik be az elméleti koncepció érvényessége.

Mivel az exploratív faktorelemzés elvetette az eredeti modell érvényességét, és a Cronbach alfával sem sikerült a modell korrekciója, ezért tovább léptünk és teszteltük, hogy egyáltalán létezik-e a vizsgált változók által determinált és az elmélet által megfogalmazott három látens változó (fogyasztóorientáció, versenytárs-orientáció, funkciók közötti együttmüködés). Mivel jelen esetben a skálák tényezői ún. reflektív indikátornak tekinthetők, azaz oksági kapcsolat feltételezhető a látens változó és az indikátor változók között, célszerü az ellenőrző faktorelemzés alkalmazásához folyamodni. Az oksági kapcsolatot azért feltételezzük, mert a látens változóink a piacorientációnak mint kultúrának részterületei, dimenziói, míg az indikátorainkkal ezeknek a dimenzióknak a megvalósulását mérjük konkrét cselekvés vagy magatartás formájában. Azaz a tényezők (indikátorok) a látható megjelenései a kultúrának (ezeket tudjuk szubjektív eszközökkel nagyobb biztonsággal mérni).

A CFA eljárás megköveteli a változók normális eloszlását, illetve a többváltozós normalitást. A változók a ferdeségi és csúcsossági mutatók alapján megfelelnek a normalitás feltételének (vagy attól csak kis mértékben térnek el), a multinormalitás azonban nem teljesül. Az alkalmazott becslöeljárás azonban biztonsággal alkalmazható a minta mérete és a többváltozós ferdeségi és csúcsossági mutatók alapján, mivel azok nem térnek el olyan mértékben a küszöbértékektől, hogy a robusztus eljárások alkalmazhatósága megkérdőjeleződjön (Neumann-Bódi 2012). A CFA modellt grafikusan építettük fel az AMOS programban, az eredeti és az adaptált modell eltérése jól látható az 1. ábrán. 

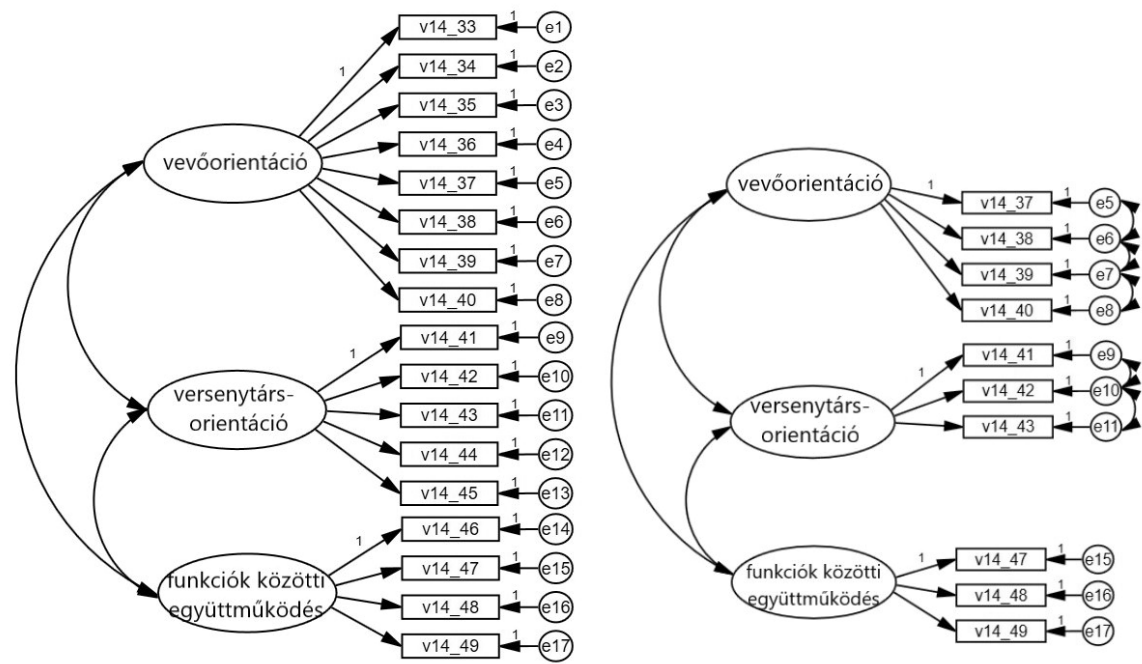

Forrás: saját szerkesztés

Ez alapján végeztük el a teljes, eredeti MKTOR modell/skála vizsgálatát, melynek során az 1. táblázatban található megfelelőségi mutatókat és kritériumokat vettük alapul. A táblázatban az is látható, hogy a megfogalmazott 6 kritériumból az eredeti modell egyet sem teljesít, ez azt jelenti, hogy az elméleti konstrukció itt is megdől (ez persze már a feltáró faktorelemzésnél is látható volt). A CFA eljárás biztosította, hogy a piacorientáció modellezését ne kelljen teljesen az alapoktól újra kezdeni, hanem egyes indikátorok törlésével, valamint a változók közötti engedmények megfogalmazásával átalakítsuk a meglévő modellt úgy, hogy a látens változók által meghatározott indikátorok egydimenziósak legyenek. Számos módosítást kellett végrehajtanunk, összesen 7 lépésben 7 indikátor eliminálásával értünk el olyan illeszkedést, mely alapján érvényesnek tekinthető a modellünk. Fontos azt megjegyeznünk, hogy az egyes kritériumok során a szakirodalomban fellelhető legszigorúbb feltételeket alkalmaztuk annak érdekében, hogy a modellünket megtisztítsuk minden torzítástól (Hooper et al. 2008). Eredményeink nagyban hasonlítanak Farrell és Oczkowski (1997) eredményeire, bár a szerzőpáros nem specifikálta a skálát, csupán a dimenzionalitást vizsgálta, ám ők is arra az eredményre jutottak, hogy a skálák tényezőinek egydimenzióssága csakis változók törlésével kivitelezhető. 
1. táblázat: A CFA modell módosításának lépései és a modell illeszkedésének mutatói $(N=217)$

Table 1. Steps of CFA model modifications and model fit indicators $(N=217)$

\begin{tabular}{llll}
\hline Mutatók & Kritérium & Eredeti modell & $\begin{array}{l}\text { Végsó, módosított } \\
\text { modell }\end{array}$ \\
\hline $\mathrm{Khi}^{2}$ & & 600,556 & 54,506 \\
$\mathrm{df}$ & 116 & 28 \\
$\mathrm{p}\left(\mathrm{Khi}^{2}\right)$ & $\geq 0,05$ & 0,000 & 0,020 \\
$\mathrm{CFI}$ & $\geq 0,95$ & 0,779 & 0,977 \\
$\mathrm{GFI}$ & $\geq 0,95$ & 0,713 & 0,953 \\
$\mathrm{NFI}$ & $\geq 0,95$ & 0,742 & 0,954 \\
$\mathrm{RMSEA}$ & $\leq 0,07$ & 0,139 & 0,066 \\
$\mathrm{p}(\mathrm{RMSEA})$ & $\geq 0,05$ & 0,000 & 0,144 \\
\hline
\end{tabular}

Forrás: Hooper et al. 2008 és saját számitás

Tovább vizsgálva az új, immáron adaptált modellünket exploratív faktorelemzéssel, arra a következtetésre jutunk, hogy a CFA során végzett szükítő/adaptáló eljárás a gyakorlatban is sikeres eredményt tükröz, mivel az új modellt képesek vagyunk három faktorral leírni úgy, hogy a faktorstruktúrában kirajzolódjanak a látens változóink (2. táblázat) $(\mathrm{KMO}=0,861$; magyarázott variancia 64,24\%).

2. táblázat: A módosított MKTOR modell faktorstruktúrája ( $N=217)$

Table 2. Factor structure of MKTOR model $(N=217)$

\begin{tabular}{|c|c|c|c|c|}
\hline Változók & & $\begin{array}{l}1 . \\
\text { faktor }\end{array}$ & $\begin{array}{l}2 . \\
\text { faktor }\end{array}$ & $\begin{array}{l}3 . \\
\text { faktor }\end{array}$ \\
\hline v14_37 & Gyakran és rendszeresen mérjük a fogyasztói elégedettséget. & 0,599 & & \\
\hline v14_38 & Nagy figyelmet fordítunk az értékesítés utáni szolgáltatásokra. & 0,674 & & \\
\hline v14_39 & $\begin{array}{l}\text { A vevőinkről szóló információknak nagy jelentőséget tulajdoní- } \\
\text { tunk a vállalaton belül. }\end{array}$ & 0,769 & & \\
\hline v14_40 & Rendszeresen gyűjtjük az információkat a vásárlóinkról. & 0,719 & & \\
\hline v14_41 & $\begin{array}{l}\text { Vállalatunk dolgozói megosztják a vállalaton belül a verseny- } \\
\text { társak stratégiájára vonatkozó információikat. }\end{array}$ & & & 0,566 \\
\hline v14_42 & $\begin{array}{l}\text { A versenytársak minket fenyegető lépéseire megfelelően } \\
\text { reagálunk. }\end{array}$ & & & 0,933 \\
\hline v14_43 & $\begin{array}{l}\text { Megfelelöen pozícionáljuk magunkat azoknál a fogyasztóknál/ } \\
\text { fogyasztói csoportoknál, ahol rendelkezünk kompetitív előny- } \\
\text { nyel, vagy képesek vagyunk ilyet kifejleszteni. }\end{array}$ & & & 0,513 \\
\hline v14_47 & $\begin{array}{l}\text { A különböző funkcionális területek között megfelelően kommu- } \\
\text { nikáljuk a fogyasztóinkkal kapcsolatos sikereket és sikertelen- } \\
\text { ségeket is. }\end{array}$ & & 0,601 & \\
\hline v14_48 & $\begin{array}{l}\text { Minden funkcionális területünk (pl. marketing, értékesítés, } \\
\mathrm{K}+\mathrm{F} \text {, könyvelés) müködése a fogyasztói igények lehető leghaté- } \\
\text { konyabb kielégítésének van alárendelve. }\end{array}$ & & 0,871 & \\
\hline v14_49 & $\begin{array}{l}\text { A vállalat vezetőinek mindegyike tisztában van azzal, hogy } \\
\text { ki hogyan tud hozzájárulni a termék fogyasztói értékének } \\
\text { létrehozásához. }\end{array}$ & & 0,700 & \\
\hline
\end{tabular}

Forrás: saját számítás 


\section{A piacorientáció és a vállalati teljesítmény kapcsolatának vizsgálata Examination of the relationship between market orientation and firm performance}

Annak érdekében, hogy ok-okozati kapcsolatot tudjunk vizsgálni a piacorientáció és a vállalati teljesítmény területei között, adatredukciót kellett végrehajtanunk, amit a piacorientáció és a vállalati teljesítmény esetében is külön-külön, dimenziónként tettünk meg fökomponens-elemzéssel, ennek eredményeit összefoglalva a 3. táblázat mutatja.

3. táblázat: Az adatredukció minőségi adatai $(N=217)$

Table 3. Qualitative data of data reduction $(N=217)$

\begin{tabular}{llll}
\hline $\begin{array}{l}\text { A piacorientáció és a vállalati teljesít- } \\
\text { mény dimenziói }\end{array}$ & $\begin{array}{l}\text { KMO } \\
\text { értéke }\end{array}$ & $\begin{array}{l}\text { Bartlett próba } \\
\text { (p-érték) }\end{array}$ & $\begin{array}{l}\text { Magyarázott } \\
\text { variancia (\%) }\end{array}$ \\
\hline Vevőorientáció & 0,770 & $<0,001$ & 68,91 \\
Versenytárs-orientáció & 0,650 & $<0,001$ & 70,47 \\
Funkciók közötti együttműködés & 0,698 & $<0,001$ & 76,30 \\
Pénzügyi teljesítmény és versenyképesség & 0,907 & $<0,001$ & 70,71 \\
Eredményesség & 0,737 & $<0,001$ & 81,92 \\
Erőforrások versenyképessége & 0,830 & $<0,001$ & 72,28 \\
\hline
\end{tabular}

Forrás: saját számitás

A skálák leírásához a Kaiser-kritérium és a varianciahányad módszer alapján valamennyi esetben elegendő volt egy komponens. A piacorientáció esetében a három dimenzió már adott volt, melyek mentén elvégeztük a fökomponens-elemzést, a vállalati teljesítménynél azonban nem ismertük a faktorstruktúrát és a változókból létrejövő új látens változókat, így még az adatredukció előtt feltáró faktorelemzést végeztünk. A vállalati teljesítményt meghatározó skálában három dimenziót azonosítottunk: pénzügyi teljesítmény és versenyképesség, eredményesség, valamint erőforrások versenyképessége. Ezek alapján a változócsoportokra külön-külön végeztük el az adatredukciót.

A piacorientáció és a vállalati teljesítmény kapcsolatát strukturális egyenlet modellezés segítségével vizsgáltuk, a modellt Raju et al. (2000) munkája alapján építettük fel. A fennálló kapcsolódásokat elöször egyenlet formájában mutatjuk be. Legyen a vevőorientáció $=x_{1}$, a versenytárs-orientáció $=x_{2}$, a funkciók közötti együttmüködés $=x_{3}$, a piacorientáció $=\gamma$, a vállalati teljesítmény $=\eta$, a pénzügyi teljesítmény és versenyképesség $=y_{1}$, az eredményesség $=y_{2}$, az eröforrások versenyképessége $=$ $y_{3}$, az együtthatók $/$ koefficiensek $=\beta$, a hibatag $=$ $e_{i}$, a véletlen, regressziós hibatag $=r_{l}$, ahol $i=1 \ldots 6$, $j=1$...7. Ekkor a modell leírható a következő egyenletekkel: $x_{1}=\beta_{1} \gamma+e_{1} ; x_{2}=\beta_{2} \gamma+e_{2} ; x_{3}=\beta_{3} \gamma+e_{3} ; y_{1}$ $=\beta_{4} \eta+e_{6} ; y_{2}=\beta_{5} \eta+e_{5} ; y_{3}=\beta_{6} \eta+e_{4} ; \eta=\beta_{7} \gamma+r_{1}$.

Az $x$ és $y$ változók a normális eloszlástól a ferdeségi és a csúcsossági mutató alapján csak kis mértékben térnek el, kvázi normálisnak tekinthetők (Huzsvai 2011, 39, Bentler \& Chou 1987), így a maximum likelihood módszer szempontjából ez nem jelent problémát. Azonban a többváltozós normalitás feltétele nem teljesül, viszont Bentler és Chou (1987) alapján elmondható, hogy a maximum likelihood eljárás elég robosztus ahhoz, hogy végrehajtható legyen e feltételek mellett is. Az egyenletek alapján képzett strukturális modell a 2. ábrán látható. 


\section{2. ábra: A strukturális egyenletek modellje \\ Figure 2. Structural equation model}

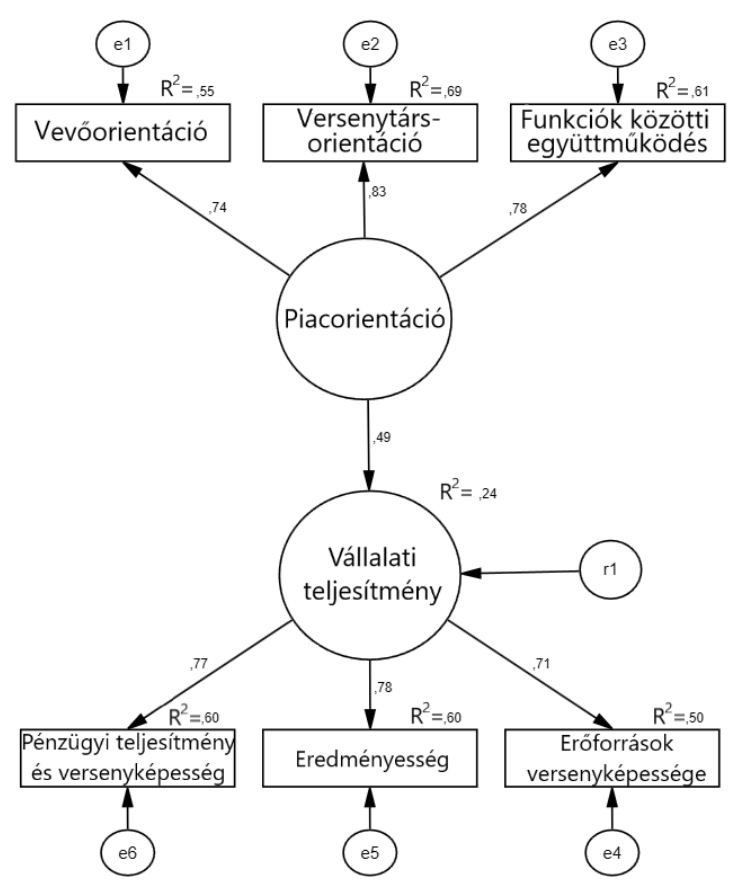

Megjegyzés: $p<0,01$ valamennyi kapcsolat esetében; $e_{i}=$ hibatag, $r_{1}=$ véletlen, regressziós hibatag, ahol $i=1 \ldots 6 ; N=163$.

Forrás: saját szerkesztés

A vizsgálatba bevont változók $\alpha=0,01$ megbízhatósági szint mellett valamennyi esetben szignifikáns magyarázóerővel rendelkeznek a modellben. A piacorientáció és a vállalati teljesítmény között szintén szignifikáns a kapcsolat 0,244-es determinációs együttható mellett. A vállalati teljesítmény és a piacorientáció közötti 0,493 értékủ koefficiens az egyenlet transzformációját követően azt jelenti, hogy a piacorientáció egy egységnyi növekedése esetén 0,493-del ( $\pm r_{l}$ hibataggal) nő a vállalati teljesítmény. Bár ez a számszerüsített összefüggés korlátozottan értelmezhető az adatredukció és az alacsony $R^{2}$ érték miatt, mégis jól mutatja, hogy a piacorientáció mértékének növekedése esetén a vállalati teljesítmény növekménye a piacorientáció növekményének közel fele. Ha megvizsgáljuk a közvetett hatásokat a piacorientáció (mint látens változó) és a vállalati teljesítmény dimenziói között, mindegyik esetben 0,3-et meghaladó mértékü és pozitív hatást tapasztalunk (pénzügyi teljesítmény és versenyképesség: 0,381 ; eredményesség: 0,383 ; erőforrások versenyképessége: 0,349 ), azaz a piacorientáció nem csupán a vállalati teljesítményre összességében van pozitív hatással, hanem annak egyes dimenzióira külön-külön is.

\section{KÖVETKEZTETÉSEK CONCLUSIONS}

Jelen kutatás eredményei azt mutatják, hogy a piacorientáció mérésére leggyakrabban alkalmazott MKTOR skála mára elavultnak tekinthetó. Az elméleti koncepció az eredeti állításokkal nem igazolódott be empirikus vizsgálatunk során, így ha ragaszkodunk Narver és Slater (1990) kulturális perspektívájához, a skála adaptálása válik szükségessé. Jelen estben az elsőgenerációs érvényességi 
vizsgálatok (Cronbach-féle alfa) sem bizonyultak elegendőnek, hogy javítsunk a skálán. A CFA-elemzés biztosíthatja, hogy az elmélet által meghatározott faktorstruktúrát alakítsunk ki, ám mérlegelni kell az eljárás hátrányait is, többek közt azt, hogy a változók törlésével mennyire torzul a kulturális elemek mérhetősége a szükített indikátorkörrel. Vizsgálatunkban a 17 indikátort tartalmazó MKTOR skálából 7 változót kellett eltávolítani, mire elértük, hogy a modell érvényes és hatásos legyen.

A vállalati teljesítmény és a piacorientáció közötti pozitív kapcsolat, melyet már számos kutatás bizonyított, jelen vizsgálat során is igazolást nyert. Másképpen fogalmazva a vállalatoknak a piacorientáció javítása érdekében tett erőfeszítései magasabb vállalati teljesítményhez vezetnek, így mindenképpen érdemes a piacorientációra kiemelt figyelmet fordítaniuk.

Véleményünk szerint a strukturális egyenlet modellezés a legjobb módszer a piacorientáció és a vállalati teljesítmény kapcsolatának vizsgálatára mindaddig, amíg e két tényezőt látens változóként értelmezzük. Bár a strukturális egyenlet modellezés során a két változó között alacsony $R^{2}$ értéket kaptunk, az eredmények szignifikánsak. Feltehetö, hogy az alacsony érték egyik oka a vállalati teljesítmény mérésére használt szubjektív skála, így célszerủ lenne a jövőben a vállalati teljesítmény szubjektív mérésére kidolgozni egy eredményesebb eszközt, esetleg megpróbálkozni az objektív teljesítményt mérő skálák használatával. Az alacsony determinációs együttható értékének további oka lehet, hogy az adatfelvétel 2010-ben történt, amikor a gazdasági válság még éreztette hatását.

Összegző javaslatunk, hogy szükséges a vizsgált területen a kutatások módszertanának fejlesztése. Felmerül a lehetőség, hogy a piacorientációs modellek érvényességi és hatásossági vizsgálata mellett a skálákat a „módszertani szükítésen” kívül bővíteni is kell a megváltozott piaci környezetnek megfelelően. A skálák tényezői egy-egy indikátor jellemzőségi fokát mérik, azonban az is figyelemre méltó lehet, hogy a szervezet döntéshozói mennyire észlelik relatíve fontosnak az adott tényezőt, hiszen a kultúra mérésére alkalmazott magatartási mutatók csak a kultúra explicit részét mérik, a szintén fontos implicit részéről pedig megfeledkeznek.

Eredményeink értékelésénél célszerü figyelembe venni néhány korlátozó tényezőt is, ami befolyásolhatja az általánosíthatóságot. Először is - bár a minta reprezentatív vállalati méretkategória és tevékenységi kör szerint, valamint véletlen mintavétellel történt a kiválasztás -, maga az adatfelvétel 2010-es, mely 2020-ban már részben elavultnak tekinthető. Ám mivel a kutatás elsődleges célki- tủzése az MKTOR skála adaptációja, valamint az adaptált modell és a vállalati teljesítmény közötti kapcsolat feltárása volt, így nem befolyásolt jelentős mértékben az adatbázis kora. A másik korlátozó feltétel magából a kérdőíves megkérdezés módszeréből fakad, melynek során a kitöltő referenciapontja és észlelése befolyásolhatja az egyes állítások megítélését a vallott-követett értékek dilemmájához hasonlóan, ezért azt mindenképp ki kell emelni, hogy mind a piacorientáció, mind a vállalati teljesítmény megítélése jelentős mértékủ szubjektivitást tartalmazhat. Érdemes továbbá megemlíteni azt is, hogy a konfirmatorikus faktorelemzésbe és a strukturális egyenlet modellezésbe az eredeti mintamérethez képest lényegesen kevesebb válaszadót tudtunk bevonni. 


\section{HIVATKOZÁSOK REFERENCES}

Avlonitis, G. J. and Gounaris, S. P. (1999), "Marketing orientation and its determinants: an empirical analysis", European Journal of Marketing, 33 11-12, 1003-1037 DOI: 10.1108/03090569910285896

Bareith T., Kövér Gy., Polereczki Zs. (2013), „A magyar élelmiszeripari kis- és közepes vállalkozások piacorientációjának mérési lehetőségei”, Élelmiszer, Táplálkozás és Marketing, 9(1), 29-37

Bentler, P. M. and Chou, C.-P. (1987), "Practical issues in structural modeling", Sociological Methods \& Research, 16(1), 78-117 DOI: 10.1177/0049124187016001004

Cronbach, L. J. (1951), "Coefficient alpha and the internal structure of tests", Psychometrika, 16(3), 297-334 DOI: 10.1007/bf02310555

Dawes, J. (2000), "Market Orientation and Company Profitability: Further Evidence Incorporating Longitudinal Data", Australian Journal of Management, 25(2), 173-199 DOI: $10.1177 / 031289620002500204$

Deshpandé, R. and Farley, J. U. (2004), "Organizational culture, market orientation, innovativeness, and firm performance: an international research odyssey", International Journal of Research in Marketing, 21(1), 3-22 DOI: 10.1016/j.ijresmar.2003.04.002

Farrell, M. A. and Oczkowski, E. (1997), "An Analysis of the MKTOR and MARKOR Measures of Market Orientation: An Australian Perspective", Marketing Bulletin, 8(3), 30-40

Farrell, M. A. (2002), "Critique of the Development of Alternative Measures of Market Orientation", Marketing Bulletin, 13(3), 1-14

Gyulavári T., Csepeti Á., Nagy G. (2011), A piacorientáció hatása a vállalati versenyképességre, Mühelytanulmány, Budapest: BCE Versenyképesség Kutató Központ

Hajjat, M. M. (2002), "Customer orientation: construction and validation of the CUSTOR scale", Marketing Intelligence and Planning, 20(7), 428-441 DOI: $10.1108 / 02634500210450864$

Harrison-Walker, J. L. (2001), "The measurement of a market orientation and its impact on business performance", Journal of Quality Management, 6(2), 139-172 DOI: 10.1016/s10848568(01)00035-9

Hooper, D., Coughlan, J. and Mullen, M. (2008), "Structural equation modelling: guidelines for determining model fit", Electronic Journal of Business Research Methonds, 6(1), 53-60

Kohli, A. K. and Jaworski, B. J. (1990), "Market Orientation: The Construct, Research Proposition and Managerial Implications", Journal of
Marketing, 54(2), 1-18 DOI: 10.2307/1251866

Kontor E. (2014a), „Az erőforrás-alapú elmélet és a marketing kapcsolódási pontjai - a piacorientáció mint marketing eröforrás", Vezetéstudomány, 45(12), 38-52

Kontor, E. (2014b), "The achievement of market orientation and its effect on performance in Hungarian SMEs", Journal of Research in Business and Management, 2(18), 1-10

Kontor E., Nyul B. (2016), „A piacorientáció érvényesülése a kis- és középvállalatok körében - egy klaszteranalízis eredményei", Competitio, 15(1), 22-45 DOI: 10.21845/comp/2016/1/2

Levine, T. R. (2005), "Confirmatory factor analysis and scale validation in communication research", Communication Research Reports, 22(4), 335338 DOI: $10.1080 / 00036810500317730$

Li, C.-H. (2016), "Confirmatory factor analysis with ordinal data: Comparing robust maximum likelihood and diagonally weighted least squares", Behavior Research Methods, 48(3), 936-949 DOI: 10.3758/s13428-015-0619-7

Narver, J. C. and Slater, S. F. (1990), "The effect of marketing orientation on business profitability", Journal of Marketing, 54(4), 20-35 DOI: $10.2307 / 1251757$

Neumann-Bódi E. (2012), Vevőértékelés egyéni és szervezeti vásárlók esetében: Az ajánlással szerzett ügyfelek jellemzői és hatásuk a vevőértékre szervezetközi viszonylatban, $P h D$ értekezés, Budapest, Budapesti Corvinus Egyetem, Gazdálkodástani Doktori Iskola

Oczkowski, E. and Farrell, M. A. (1998a), "Discriminating between measurement scales using non-nested tests and two-stage least squares estimators: the case of market orientation", International Journal of Research in Marketing, 15(4), 349-366 DOI: 10.1016/s01678116(98)00007-x

Oczkowski, E. and Farrell, M. A. (1998b), “An examination of the form of market orientation in Australian companies", Australasian Marketing Journal, 6(2), 3-12 DOI: 10.1016/s14413582(98)70245-9

Raju, P. S., Lonial S. C., Gupta, Y. P. and Ziegler C. (2000), "The relationship between market orientation and performance in the hospital industry: A structural equations modeling approach", Health Care Management Science, 3(3), 237247 DOI: 10.1023/A:1019061912075

Rekettye, G. and Gupta, A. K. (1995), "Half-way towards market economy: Market orientation of the Hungarian manufacturing companies", Marketing \& Management, 29(1), 27-32

Tomáskova, E. (2009), "The Current Methods of Measurement of Market Orientation", European Research Studies, 12(3), 135-150 
Kiss Marietta $\mathrm{PhD}$, adjunktus kiss.marietta@econ.unideb.hu

Szakály Zoltán CSc, intézetigazgató egyetemi tanár szakaly.zoltan@econ.unideb.hu

Kovács Bence, $\mathrm{PhD}$ hallgató kovacs.bence@econ.unideb.hu

Debreceni Egyetem Gazdaságtudományi Kar

\section{MELLÉKLETEK APPENDICES}

\section{1. melléklet: Az MKTOR skála} Appendix 1. MKTOR scale

\begin{tabular}{|c|c|}
\hline & Vevöorientáció \\
\hline v14_33* & Vállalati céljaink kialakítását a fogyasztói elégedettség elérése motiválja. \\
\hline v14_34* & $\begin{array}{l}\text { Nyomon követjük a szervezet fogyasztói igények kielégítésének irányába történő elkötele- } \\
\text { zettségét. }\end{array}$ \\
\hline v14_35* & A kompetitív előnyöket kihasználó stratégiánk a fogyasztói igények megértésén alapul. \\
\hline v14_36* & $\begin{array}{l}\text { Üzleti stratégiánk mozgatórugója azon meggyőződésünk, hogy hogyan tudunk nagyobb } \\
\text { értéket előállítani vásárlóink számára. }\end{array}$ \\
\hline v14_37 & Gyakran és rendszeresen mérjük a fogyasztói elégedettséget. \\
\hline v14_38 & Nagy figyelmet fordítunk az értékesítés utáni szolgáltatásokra. \\
\hline v14_39 & A vevőinkről szóló információknak nagy jelentőséget tulajdonítunk a vállalaton belül. \\
\hline \multirow[t]{2}{*}{ v14_40 } & Rendszeresen gyüjtjük az információkat a vásárlóinkról. \\
\hline & Versenytárs-orientáció \\
\hline v14_41 & $\begin{array}{l}\text { Vállalatunk dolgozói megosztják a vállalaton belül a versenytársak stratégiájára vonatkozó } \\
\text { információikat. }\end{array}$ \\
\hline v14_42 & A versenytársak minket fenyegető lépéseire megfelelően reagálunk. \\
\hline v14_43 & $\begin{array}{l}\text { Megfelelően pozícionáljuk magunkat azoknál a fogyasztóknál/fogyasztói csoportoknál, ahol } \\
\text { rendelkezünk kompetitív előnnyel, vagy képesek vagyunk ilyet kifejleszteni. }\end{array}$ \\
\hline v14_44* & $\begin{array}{l}\text { A versenytársaink tevékenységéről szóló információknak nagy jelentőséget tulajdonítunk a } \\
\text { vállalaton belül. }\end{array}$ \\
\hline \multirow[t]{2}{*}{ v14_45* } & Rendszeresen gyüjtjük az információkat a versenytársainkról. \\
\hline & Funkciók közötti együttmüködés \\
\hline v14_46* & $\begin{array}{l}\text { A vállalat különböző funkcionális területeinek első számú vezetői felkeresik a jelenlegi és } \\
\text { jövőbeni várható partnereinket. }\end{array}$ \\
\hline v14_47 & $\begin{array}{l}\text { A különböző funkcionális területek között megfelelően kommunikáljuk a fogyasztóinkkal } \\
\text { kapcsolatos sikereket és sikertelenségeket is. }\end{array}$ \\
\hline v14_48 & $\begin{array}{l}\text { Minden funkcionális területünk (pl.: marketing, értékesítés, } \mathrm{K}+\mathrm{F} \text {, könyvelés) müködése a } \\
\text { fogyasztói igények lehető leghatékonyabb kielégítésének van alárendelve. }\end{array}$ \\
\hline v14_49 & $\begin{array}{l}\text { A vállalat vezetőinek mindegyike tisztában van azzal, hogy ki hogyan tud hozzájárulni a } \\
\text { termék fogyasztói értékének létrehozásához. }\end{array}$ \\
\hline
\end{tabular}

Megjegyzés: * A végső modellböl törölt változók.

Forrás: Narver \& Slater (1990) alapján saját átdolgozás 


\section{2. melléklet: A vállalati teljesítményt mérő skála \\ Appendix 2. Firm performance scale}

\begin{tabular}{|c|c|}
\hline v15_1a & $\begin{array}{l}\text { Vállalkozásunk előző évi teljesítménye összességében a legnagyobb versenytársainkhoz } \\
\text { hasonlóan alakult. }\end{array}$ \\
\hline v15_2a & Vállalkozásunk piaci részesedése nőtt legjelentősebb felvevő piacunkon az elmúlt évben. \\
\hline v15_3a & $\begin{array}{l}\text { Vállalkozásunk előző évi értékesítési növekedése összességében a legnagyobb versenytár- } \\
\text { sainkhoz hasonlóan alakult. }\end{array}$ \\
\hline v15_4a & $\begin{array}{l}\text { Az általunk bevezetett új termékek értékesítésben betöltött részaránya a legnagyobb } \\
\text { versenytársainkhoz hasonlóan alakult az előző évben. }\end{array}$ \\
\hline v15_5a & $\begin{array}{l}\text { Vállalkozásunk árbevétel-arányos nyeresége (return on sales - ROS) nem maradt el a } \\
\text { legnagyobb versenytársunkhoz képest az előző évben. }\end{array}$ \\
\hline v15_6a & $\begin{array}{l}\text { Vállalkozásunk eszközarányos nyeresége (return on assets - ROA) nem maradt el a leg- } \\
\text { nagyobb versenytársunkhoz képest az előző évben. }\end{array}$ \\
\hline v15_7a & $\begin{array}{l}\text { Vállalkozásunk befektetéseinek megtérülése (return on investment - ROI) nem maradt el } \\
\text { a legnagyobb versenytársunkhoz képest az előző évben. }\end{array}$ \\
\hline v15_8b & A profitcéljainkat teljes mértékben teljesítettük az előző pénzügyi évben. \\
\hline v15_9b & Az értékesítési céljainkat teljes mértékben teljesítettük az előző pénzügyi évben. \\
\hline $\mathrm{v} 15 \_10 \mathrm{~b}$ & A befektetés-megtérülési (ROI) céljainkat elértük az előző pénzügyi évben. \\
\hline v15_11c & Termékeink minősége magasabb szintet ért el az előző évben, mint versenytársainké. \\
\hline $\mathrm{v} 15_{-} 12 \mathrm{c}$ & Az ügyfél-megtartási képességünk (customer retention rate) jobb, mint a versenytársainké. \\
\hline v15_13c & $\begin{array}{l}\text { Jobb hírnevünk van a legföbb fogyasztói célcsoportunk körében, mint a } \\
\text { versenytársainknak. }\end{array}$ \\
\hline v15_14c & $\begin{array}{l}\text { Alkalmazottaink fluktuációja (employee turnover rate) alacsonyabb, } \\
\text { mint versenytársainké. }\end{array}$ \\
\hline v15_15c & eredményesebbek vagyunk az új termékek fejlesztése terén, mint versenytársaink. \\
\hline
\end{tabular}

Megjegyzések: $a$ : pénzügyi teljesitmény és versenyképesség, $b$ : eredményesség, $c$ : erőforrások versenyképessége.

Forrás: saját szerkesztés 


\section{Adaptation of the MKTOR model measuring market orientation and its relationship with business performance}

\section{THE AIMS OF THE PAPER}

This study aimed to examine the relationship between the market orientation and the performance of SMEs in the Hungarian food and agriculture sector.

\section{METHODOLOGY}

The market orientation was defined by the internationally validated MKTOR scale, which has been adapted to and validated for the Hungarian food and agriculture sector by using exploratory and confirmatory factor analysis. The business performance was measured by a three-dimension indicator based on the subjective perception of performance. The basis of the primary research was a personal interview survey representative by firm size and scope of activity, conducted among the marketing staff (or in the absence of this, the executives) of 250 agricultural and food sector firms, queried by interviewers. The relationship between market orientation and business performance was tested by structural equation modelling (SEM).

\section{MOST IMPORTANT RESULTS}

Based on our primary research, the most common measure of market orientation, i.e. the MKTOR scale can be seen as obsolete now. Besides, SEM revealed a positive relationship between the extent of market orientation and the performance of the firms, moreover, similar relationships were found between the market orientation and the specific dimensions of business performance.

\section{RECOMMENDATIONS}

For the researchers to gain accurate understanding of market orientation, it is necessary to develop the methodology related to the research of market orientation, as well as to adapt the scales measuring market orientation. Since an increase in the market orientation leads to better performance, businesses have to place particular emphasis on developing their market orientation.

Keywords: market orientation, MKTOR, business performance, food and agriculture sector

Acknowledgement: This publication was supported by the EFOP-3.6.2-16-2017-00003 project. The project is co-financed by the European Union and the European Social Fund. 